\title{
Characterization of the Interactions between Endocrine Disruptors and Aquatic Humic Substances from Tropical Rivers
}

\author{
Wander G. Botero, ${ }^{a}$ Luciana C. de Oliveira, ${ }^{b}$ Bruno B. Cunha, ${ }^{c, d}$ Lílian K. de Oliveira, ${ }^{c, d}$ \\ Danielle Goveia, ${ }^{c, d}$ Julio Cesar Rocha, ${ }^{c}$ Leonardo F. Fraceto ${ }^{d}$ and André Henrique Rosa ${ }^{*, d}$ \\ ${ }^{a}$ Federal University of Alagoas (UFAL), CP 61, 57309-005 Arapiraca-AL, Brazil \\ ${ }^{b}$ Federal University of São Carlos (UFSCar), 18052-780 Sorocaba-SP, Brazil \\ ${ }^{c}$ Department of Analytical Chemistry, Institute of Chemistry, São Paulo State University (UNESP), \\ CP 355, 14801-970 Araraquara-SP, Brazil
}

${ }^{d}$ Department of Environmental Engineering, São Paulo State University (UNESP), 18087-180 Sorocaba-SP, Brazil

\begin{abstract}
Interações entre substâncias húmicas aquáticas (SHA), de rios tropicais, e dois interferentes endócrinos (IE) foram estudados utilizando sistema de ultrafiltração em fluxo tangencial equipado com membrana de celulose de $1 \mathrm{kDa}$ com a finalidade de separar os IE livres da fração ligada as SHA. A quantificação de $17 \alpha$-etinilestradiol e bisfenol A foi realizada utilizando cromatógrafo a gás acoplado a espectrômetro de massas (GC-MS). O tempo de equilíbrio entre as SHA e IE foi de aproximadamente $30 \mathrm{~min}$, e as capacidades complexantes do $17 \alpha$-etinilestradiol e bisfenol A foram em torno de 18,53 e 2,07 $\mathrm{mg} \mathrm{g}^{-1}$ de carbono orgânico total (COT), respectivamente. A maior interação das SHA ocorreu para $17 \alpha$-etinilestradiol, em relação ao bisfenol A, devido a presença de hidrogênio na estrutura do $17 \alpha$-etinilestradiol, que podem interagir com os grupos oxigenados presentes nas SHA. Os resultados indicam que as SHA podem influenciar fortemente no transporte e reatividade dos interferentes endócrinos presentes em sistemas aquáticos.
\end{abstract}

Interactions between two endocrine disruptors (ED) and aquatic humic substances (AHS) from tropical rivers were studied using an ultrafiltration system equipped with a $1 \mathrm{kDa}$ cut-off cellulose membrane to separate free ED from the fraction bound in the AHS. Quantification of $17 \alpha$-ethynylestradiol and bisphenol A was performed using gas chromatography-mass spectrometry (GC-MS). The times required for establishment of equilibrium between the AHS and the ED were $c a .30 \mathrm{~min}$, and complexation capacities for $17 \alpha$-ethynylestradiol and bisphenol A were 18.53 and $2.07 \mathrm{mg} \mathrm{g}^{-1}$ TOC, respectively. The greater interaction of AHS with $17 \alpha$-ethynylestradiol, compared to bisphenol $\mathrm{A}$, was due to the presence of hydrogen in the structure of $17 \alpha$-ethynylestradiol, which could interact with ionized oxygenated groups of the AHS. The results indicate that AHS can strongly influence the transport and reactivity of endocrine disruptors in aquatic systems.

Keywords: water, pollution, endocrine disruptors, aquatic humic substances, complexation capacity

\section{Introduction}

Population increase, the development of new products, and intensified use of terrestrial and aquatic resources in industry and agriculture have resulted in the introduction into the environment of new compounds that may cause toxicity in humans and animals. Endocrine disruptors (ED)

*e-mail: ahrosa@sorocaba.unesp.br are often found in surface waters and effluents, where they can pose health risks even at low concentrations. In 1996, the European Commission defined this class of compounds as "exogenous substances that cause adverse health effects in the intact organism, or in its descendents, resulting in alterations of endocrine functions" ${ }^{1,2}$

ED can block cellular receptor sites or increase the production and/or secretion of hormones, hence interfering in the reproductive systems of living organisms..$^{3-5}$ Many 
compounds are suspected of interfering with the endocrine system, ${ }^{6}$ including natural and synthetic estrogens (lipidsoluble steroid hormones) such as $17 \alpha$-ethynylestradiol, polycyclic aromatic hydrocarbons (compounds containing two or more conjugated aromatic rings, such as benzo(a) anthracene), polychlorinated biphenyls (highly toxic chlorinated compounds), pesticides (substances such as dichlorodiphenyltrichloroethane (DDT), used to repel or eliminate pathogenic insects), and plasticisers such as bisphenol A that are used in polymeric plastics. ${ }^{7}$

ED are conveyed to aquatic systems by various natural or anthropogenic mechanisms. Their presence in surface waters is often due to discharge of domestic and/or industrial effluents. ${ }^{8}$ ED contamination of aquatic systems is especially problematic because most conventional water treatment processes are unable to completely eliminate the compounds. ${ }^{9}$ Studies have found residues of pharmaceuticals and their metabolites, from $\mathrm{n} \mathrm{L}^{-1}$ to $\mu \mathrm{g} \mathrm{L}^{-1}$ levels, in aquatic environments in countries including Germany, Brazil, Canada, Holland, UK, Italy, Sweden and the USA. ${ }^{10-13}$ However, since these chemicals belong to an emerging class of pollutants, the literature is still sparse concerning their behavior and interactions in hydric systems.

Aquatic humic substances (AHS), the most important class of complexation agents present in the natural environment, play an important role in the transport and behavior of ED. ${ }^{14}$ Characterization of the interactions of ED with AHS, exploring the formation and stability of possible ED-AHS complexes, can therefore provide important information concerning the availability of ED to aquatic biota.

This work presents the use of a procedure based on ultrafiltration to study the interactions between endocrine disruptors (17 $\alpha$-ethynylestradiol and bisphenol A) and aquatic humic substances extracted from two different tropical rivers, using measurements of equilibrium time, complexation capacity and competition between the ED for AHS complexation sites.

\section{Experimental}

\section{Chemicals and reagents}

All the reagents used were high-purity grade. The acid and alkaline solutions required for AHS isolation were prepared by diluting $30 \%$ hydrochloric acid or sodium hydroxide monohydrate (both Suprapure, Merck AG, Germany) in deionized water (resistivity $18.2 \mathrm{M} \Omega \mathrm{cm}$ at $25{ }^{\circ} \mathrm{C}$, Milli-Q system, Millipore, USA). The XAD-8 adsorbent (Serva Feinbiochemica, Germany) required for the isolation of AHS was pre-purified by successive soakings with $0.5 \mathrm{~mol} \mathrm{~L}^{-1} \mathrm{HCl}, 0.5 \mathrm{~mol} \mathrm{~L}^{-1} \mathrm{NaOH}$ and methanol ( $24 \mathrm{~h}$ each). Stock solutions of bisphenol A and $17 \alpha$-ethynylestradiol (Sigma-Aldrich) were prepared by dissolution in acetonitrile (Merck AG, Germany).

\section{Water sampling and preliminary analysis}

The Itapanhaú River is located in the Serra do Mar State Park (latitude: $23^{\circ} 50^{\prime} 23^{\prime \prime} \mathrm{S}$; longitude: $46^{\circ} 08^{\prime} 21^{\prime \prime} \mathrm{W}$ ), an environmentally protected area of the municipality of Bertioga, São Paulo State, Brazil. The Ribeira do Iguape River is situated close to the Juréia Ecological Station (latitude: $24^{\circ} 41^{\prime} 59^{\prime \prime} \mathrm{S}$; longitude: $47^{\circ} 33^{\prime} 05^{\prime \prime} \mathrm{W}$ ), in the municipality of Iguape, São Paulo State. These regions have a subtropical climate, with pluviometric index of $c a$. $2700 \mathrm{~mm}$ per year, humidity of $c a .80 \%$, and $c a .150$ and ca. $97 \mathrm{~h}$ per month of sun in January and July, respectively.

The $\mathrm{pH}$, temperature, conductivity and dissolved oxygen content of water samples were determined in situ after calibration of the equipment (using standard reference solutions where appropriate). In the laboratory the water samples were digested at $120^{\circ} \mathrm{C}$ using concentrated $\mathrm{HNO}_{3}$, and the concentrations of the metals $\mathrm{Cu}, \mathrm{Cd}, \mathrm{Fe}, \mathrm{Mn}$ and $\mathrm{Ni}$ determined by graphite furnace atomic absorption spectroscopy (GFAAS). The dissolved organic carbon (DOC) contents of the AHS concentrate and the humic fractions were determined by catalytic combustion in an oxygen stream, with IR detection, using a total organic carbon analyzer - Shimadzu TOC 5000. ${ }^{15}$

Table 1 lists the results of the preliminary characterization of the water samples. Extracts from two different rivers were used in order to explore the influence of environmental factors on the formation, decomposition and structural characteristics of AHS and, consequently, their interactions with $17 \alpha$-ethynylestradiol and bisphenol A.

\section{Isolation of aquatic humic substances using XAD-8 resin}

The AHS were concentrated by filtration of the water samples through $0.45 \mu \mathrm{m}$ cellulose-based membranes, acidified to $\mathrm{pH}<2$ with $0.5 \mathrm{~mol} \mathrm{~L}^{-1} \mathrm{HCl}$, and isolated on the XAD- 8 collector, following the recommendations of Aiken et al. ${ }^{16}$ After elution with $0.1 \mathrm{~mol} \mathrm{~L}^{-1} \mathrm{NaOH}$, the AHS concentrate was acidified to $\mathrm{pH} 5.0$ with $0.1 \mathrm{~mol} \mathrm{~L}^{-1}$ $\mathrm{HCl}$ solution, evaporated under vacuum, and oven-dried in re-circulating air at $55^{\circ} \mathrm{C} .{ }^{15}$

\section{Characterization of the aquatic humic substances}

The elemental composition (considering $\mathrm{C}, \mathrm{H}, \mathrm{O}, \mathrm{N}$ and S) of the AHS was determined using a Thermo Finnigan 
Table 1. Preliminary characterization of water samples collected from tributaries of the Itapanhaú and Ribeira de Iguape Rivers

\begin{tabular}{|c|c|c|}
\hline \multirow[t]{2}{*}{ Parameter } & \multicolumn{2}{|c|}{ Water sample } \\
\hline & Itapanhaú & Ribeira de Iguape \\
\hline $\mathrm{pH}$ & $4.4 \pm 0.2$ & $5.8 \pm 0.2$ \\
\hline Temperature $\left({ }^{\circ} \mathrm{C}\right)$ & $23.0 \pm 0.1$ & $21.0 \pm 0.1$ \\
\hline Conductivity $\left(\mu \mathrm{S} \mathrm{cm}^{-1}\right)$ & $39.0 \pm 0.4$ & $303.0 \pm 0.5$ \\
\hline Dissolved oxygen $\left(\mathrm{mg} \mathrm{L}^{-1}\right)$ & $2.2 \pm 0.2$ & $5.1 \pm 0.2$ \\
\hline Total organic carbon $\left(\mathrm{mg} \mathrm{L}^{-1}\right)$ & $15.3 \pm 2.1$ & $37.8 \pm 2.4$ \\
\hline Absorbance at $436 \mathrm{~nm}$ (A) & 0.085 & 0.220 \\
\hline Molar absorptivity $\left(\mathrm{L} \mathrm{cm}^{-1} \mathrm{~mol}^{-1}\right)$ & 66.7 & 71.4 \\
\hline $\mathrm{Fe}\left(\mu \mathrm{g} \mathrm{L}^{-1}\right)$ & $909.0 \pm 0.4$ & $1455.0 \pm 5.82$ \\
\hline $\operatorname{Mn}\left(\mu \mathrm{g} \mathrm{L}^{-1}\right)$ & $250.1 \pm 0.6$ & $50.6 \pm 0.3$ \\
\hline $\mathrm{Cu}\left(\mu \mathrm{g} \mathrm{L}^{-1}\right)$ & $0.83 \pm 0.1$ & $3.2 \pm 0.1$ \\
\hline $\mathrm{Pb}\left(\mu \mathrm{g} \mathrm{L}^{-1}\right)$ & $7.3 \pm 0.5$ & $1.3 \pm 0.2$ \\
\hline $\mathrm{Ni}\left(\mu \mathrm{g} \mathrm{L}^{-1}\right)$ & $30.8 \pm 0.7$ & $6.8 \pm 0.6$ \\
\hline
\end{tabular}

LOD $\left(\mu \mathrm{g} \mathrm{L}^{-1}\right): 2.17(\mathrm{Cu}) ; 4.97(\mathrm{~Pb}) ; 2.67(\mathrm{Ni}) ; 2.12(\mathrm{Fe}) ; 3.89(\mathrm{Mn})$. LOQ $\left(\mu \mathrm{g} \mathrm{L}^{-1}\right)$ : $7.24(\mathrm{Cu}) ; 16.67(\mathrm{~Pb}) ; 9.65(\mathrm{Ni}) ; 8.78(\mathrm{Fe}) ; 11.39(\mathrm{Mn})$.

Flash EA 1112 elemental analyzer. ${ }^{13} \mathrm{C}$ nuclear magnetic resonance (NMR) experiments, with crossed polarization (CP) and variable amplitude (VA) magic angle spinning (MAS), were performed using a Varian Unity Inova 400 spectrometer. The AHS samples were conditioned in a $5 \mathrm{~mm}$ diameter cylindrical zirconium rotor (Doty Supersonic), rotating at $6 \mathrm{kHz}$. The ${ }^{13} \mathrm{C}$ VACP/MAS NMR spectra were acquired under the following experimental conditions: ${ }^{13} \mathrm{C}$ resonance frequency of $100.05 \mathrm{MHz}$; crossed polarization spectral band of $20 \mathrm{kHz} ; 3.8 \mu$ s proton preparation pulse; $1 \mathrm{~ms}$ contact time; $12.8 \mathrm{~ms}$ acquisition time; $500 \mathrm{~ms}$ relaxation time. The chemical shift $(\delta)$ values were referenced to hexamethyl benzene (HMB), which possesses a well defined line at $17.2 \mathrm{ppm}$.

Interaction of aquatic humic substances and endocrine disruptors

The analytical procedure proposed by Burba et $a l .{ }^{17}$ based on ultrafiltration, was used for studies of the interactions between the AHS and the ED (Figure 1). This technique employed a tangential ultrafiltration system (Sartorius Ultrasart X), fitted with a $1 \mathrm{kDa}$ membrane (Gelman Pall-Filtron OMEGA) to separate AHS-ED complexes larger than $1 \mathrm{kDa}$ from the free ED.

\section{Determination of the time to equilibrium of complexation between AHS and ED}

Kinetic studies of HS complexation provide important information concerning the minimum time necessary for

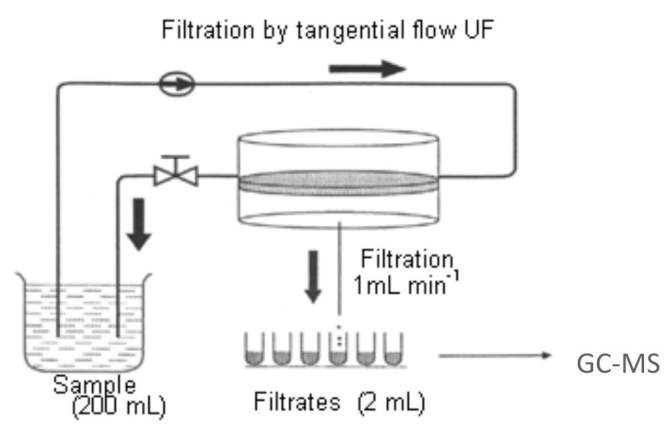

Figure 1. Ultrafiltration system equipped with a $1 \mathrm{kDa}$ membrane, used for the separation of free bisphenol A and $17 \alpha$-ethynylestradiol from the same compounds complexed by aquatic humic substances.

a given species to form a complex with AHS. Volume of $8.0 \mathrm{~mL}$ of a solution of $5.0 \mathrm{mg} \mathrm{L}^{-1} 17 \alpha$-ethynylestradiol and bisphenol A were added to $192.0 \mathrm{~mL}$ of a solution of $20 \mathrm{mg} \mathrm{L}^{-1} \mathrm{AHS}$, and 10 aliquots of $1.0 \mathrm{~mL}$ were collected after between 5 and $210 \mathrm{~min}$. The ED were determined by gas chromatography-mass spectrometry, and the equilibrium time was obtained by plotting the concentration of the free species as a function of time.

\section{Determination of the complexation capacity of AHS for ED}

Titrations were performed using $20 \mathrm{~mL}$ volumes of $20 \mathrm{mg} \mathrm{L}^{-1}$ AHS solution, adjusted to $\mathrm{pH} 5.0$ using $0.1 \mathrm{~mol} \mathrm{~L}^{-1} \mathrm{NaOH}$ solution. The system was allowed to pump for about $5 \mathrm{~min}$ prior to addition of the ED solution, to condition the membrane. The first aliquot (ca. $2 \mathrm{~mL}$ ) was then filtered, corresponding to time zero (before addition of the ED solution). Aliquots of the ED solution were then added to the AHS solution to achieve final ED concentrations of 10, 20, 30, 50, $70,90,110,130$ and $140 \mu \mathrm{g} \mathrm{L}{ }^{-1}$. The mixture was kept under agitation for $30 \mathrm{~min}$ between each addition, to assist attainment of exchange equilibrium. Aliquots (ca. $2 \mathrm{~mL}$ ) were collected, and the ED concentrations determined by GC-MS. The complexation capacity of the AHS was obtained by plotting the concentration of ED added against that of free ED (separated using the ultrafiltration system).

\section{Competition between endocrine disruptors for the AHS}

Using quantities based on the complexation capacities of the AHS, $2 \mathrm{~mL}$ of each $20 \mathrm{mg} \mathrm{L}^{-1} \mathrm{ED}$ standard solution were added to $196 \mathrm{~mL}$ of a $20 \mathrm{mg} \mathrm{L}^{-1}$ AHS solution, and the $\mathrm{pH}$ adjusted to $\mathrm{pH} 5.0$ using a $0.1 \mathrm{~mol} \mathrm{~L}^{-1} \mathrm{NaOH}$ solution. The system was allowed to pump for around $5 \mathrm{~min}$, prior to addition of the ED solutions, in order to condition the membrane. The sample was then ultrafiltered, and $c a$. of $1.0 \mathrm{~mL}$ aliquots of the free ED solution were removed after 0, 10, $30 \mathrm{~min}, 1,2$, $3,4,5,6,7,8,24,48$ and $72 \mathrm{~h}$. 


\section{Chromatography analysis}

Optimization of the solid phase extraction (SPE) of analytes using Nexus cartridges (Varian) was performed according to the manufacturer's recommended procedure for endocrine disruptors. Firstly, a $10 \mathrm{~mL}$ portion of each sample was passed through a $3 \mathrm{~mL}$ Nexus cartridge filled with $60 \mathrm{mg}$ of the sorbent. After drying under vacuum, the cartridges were eluted with $5 \mathrm{~mL}$ of a methanol/ ethyl acetate (10:90, v/v) solution. The extract was then derivatized, after evaporation of the elutant solution.

Derivatization of standard solutions and samples was performed in test tubes, following the procedure proposed by Jeannot et al. ${ }^{1}$ A $500 \mu \mathrm{L}$ portion of the standard solution or sample was evaporated to dryness at $30^{\circ} \mathrm{C}$, after which $50 \mu \mathrm{L}$ of N,O-bis(trimethylsilyl)-trifluoroacetamide (BSTFA) was added. The test tube was closed, and placed in a water bath at $60{ }^{\circ} \mathrm{C}$ for $30 \mathrm{~min} .500 \mu \mathrm{L}$ of Isooctane was added, and the tube placed in an ultrasonic bath for $10 \mathrm{~min}$. After derivatization, the sample and standard solutions were made up to $1.0 \mathrm{~mL}$ in volumetric flasks, and were then ready for injection into the GC-MS.

A Varian (Les Ulis, France) GC-MS system was employed, consisting of a Model 450-GC gas chromatograph equipped with a Model 1079 split-plitless temperatureprogrammed injector and a 200-MS ion-trap mass spectrometer. Varian Saturn 2000 software was used for data processing. The injector contained a treated Siltek $2.0 \mathrm{~mm}$ i.d. liner filled with glass wool. Large volume $(40 \mu \mathrm{L})$ injections of derivatized extracts or derivatized standard solutions were used. The injector temperature was initially set at $90{ }^{\circ} \mathrm{C}$, where it was maintained for $1.5 \mathrm{~min}$, then increased at a rate of $200{ }^{\circ} \mathrm{C} \mathrm{min}^{-1}$ to $300{ }^{\circ} \mathrm{C}$, where it was maintained for $12.4 \mathrm{~min}$. The split-splitless valve operated in split mode from 0 to $1.5 \mathrm{~min}$, in splitless mode from 1.5 to $3.0 \mathrm{~min}$, then back in split mode from 3.0 to $15.0 \mathrm{~min}$.
Compounds were separated on a $30 \mathrm{~m} \times 0.25 \mathrm{~mm}$ i.d. VF-5ms column (95\% dimethyl - 5\% phenyl polysiloxane; Varian-Chrompack, Les Ulis, France). The column temperature was initially set at $90^{\circ} \mathrm{C}$ for a period of $0.5 \mathrm{~min}$, and then increased to $240{ }^{\circ} \mathrm{C}$ at a rate of $30^{\circ} \mathrm{C} \mathrm{min}^{-1}$. The rate of increase was then slowed to $5^{\circ} \mathrm{C} \mathrm{min}^{-1}$, up to a final temperature of $280^{\circ} \mathrm{C}$, which was maintained for $1.5 \mathrm{~min}$. Helium was used as the carrier gas, at a constant flow rate of $1.2 \mathrm{~mL} \mathrm{~min}^{-1}$. Data acquisition was performed in full scan mode, from 50 to $650 \mu$ at $1 \mathrm{~s} \mathrm{scan}^{-1}$. The transfer line temperature was set at $280{ }^{\circ} \mathrm{C}$. For the chromatographic conditions used, retention times and quantification ions were $7.97 \mathrm{~min}$ and $\mathrm{m} / z 357$ for bisphenol A, and $12.73 \mathrm{~min}$ and $m / z, 368$ and 285 for $17 \alpha$-ethynylestradiol.

\section{Results and Discussion}

The AHS were characterized using atomic ratios $(\mathrm{C} / \mathrm{H}$ and $\mathrm{C} / \mathrm{O}$ ) calculated from the elemental measurements, and functional groups obtained from the ${ }^{13} \mathrm{C}$ NMR analyses (Table 2). Comparing the $\mathrm{C} / \mathrm{H}$ atomic ratios, ${ }^{20-22}$ the Ribeira de Iguape AHS samples appeared to be more aromatic in nature than the Itapanhaú samples. The $\mathrm{C} / \mathrm{O}$ atomic ratio is related to the carbohydrate content, with elevated values indicating a greater degree of humification, due to the loss of carbohydrate $-\mathrm{COOH}$ and $-\mathrm{OH}$ groups (both aromatic and aliphatic). Here, the $\mathrm{C} / \mathrm{O}$ atomic ratios reflected very similar distributions of oxygenated groups in the structures of the AHS, which were also similar to those previously reported in the literature.

Observations of the types of carbon present in the samples (using ${ }^{13} \mathrm{C}$ NMR spectra) showed the existence of structural differences between the AHS extracted from the two watersheds, which were also different to those reported in the literature. ${ }^{18,19}$ Such differences are related to the process of decomposition of the original

Table 2. ${ }^{13} \mathrm{C}$ NMR atomic ratio $(\mathrm{C} / \mathrm{H}, \mathrm{C} / \mathrm{O})$ and functional group results for samples of aquatic humic substances obtained from the Itapanhaú (IT) and Ribeira do Iguape (RDI) Rivers, and as reported in the literature

\begin{tabular}{lccccc}
\hline Parameter & & & Sample & & \\
& IT & RDI & Itapanhaú $^{18}$ & Rio Negro $^{18}$ & Rio Negro $^{19}$ \\
\hline C/H & 0.84 & 0.95 & 3.7 & 3.6 & 8.5 \\
C/O & 1.1 & 1.1 & 1.2 & 1.2 & 0.9 \\
Aliphatic (\%) & 34.2 & 31.9 & 25.0 & 12.1 & 32.0 \\
Ether (\%) & 20.0 & 16.6 & 15.2 & 38.0 & 22.0 \\
Aromatic (\%) & 23.1 & 22.8 & 33.6 & 6.2 & 11.0 \\
Phenol (\%) & 3.2 & 5.3 & 4.8 & 15.0 & 14.0 \\
Carboxyls, ethers and amides (\%) & 13.7 & 13.4 & 2.9 & 5.0 & 11.0 \\
Aldehydes and ketones (\%) & 5.8 & 9.9 & & & \\
\hline
\end{tabular}


organic matter, with transformations being dependent on the type of substrate, the presence and characteristics of microorganisms, and other environmental factors such as solar radiation intensity, temperature, oxygen availability and $\mathrm{pH}^{23,24}$ Sun et al. ${ }^{25}$ suggested that the abundance of aromatic rings in the structure of organic matter is an important factor influencing the sorption of endocrine disruptors. This emphasizes the importance of the characterization of the organic matter present in humic substances.

Figure 2(A and B) shows typical curves obtained during determination of the complexation equilibrium time, for $17 \alpha$-ethynylestradiol with AHS from the Ribeira de Iguape River (A), and for bisphenol A with AHS from the Itapanhaú River (B). According to Oliveira et al. ${ }^{23}$ complexes with organic matter tend to stabilize as a function of time, due to inter- and/or intramolecular rearrangements and transfer of complexing species to complexation sites deeper within the molecules. Complexation equilibrium between the ED and AHS extracted from the different rivers was achieved after about $20 \mathrm{~min}$ (for both ED). These results are comparable to those obtained previously in studies of the complexation of HS, extracted from different matrices, with potentially toxic inorganic species, where the kinetics of complexation was around $30 \mathrm{~min}^{.}{ }^{15,26}$

During titration with endocrine disruptors, saturation of the strongest AHS binding sites occurs first, followed by saturation of the weaker sites. Figure 3 shows a typical titration of AHS with a standard solution of bisphenol A, using the tangential flow ultrafiltration procedure. The complexation capacity (CC) was determined by plotting the free ED concentration as a function of the total ED concentration. The curve shows a slope change, and the complexation capacity was obtained from the intersection of the two linear sections. ${ }^{26,27}$ No comparative results have been reported in the literature concerning the complexation capacities of AHS for endocrine disruptors. Table 3 presents the complexation capacities of AHS for some organic and inorganic substances, including the results of the present study.

The AHS from both sources showed greater affinity for $17 \alpha$-ethynylestradiol than for bisphenol $\mathrm{A}$. This can be explained by the behavior of the ED molecules at the AHS complexation sites, which is largely governed by the quantity of $-\mathrm{OH}$ groups present, with formation of hydrogen bond type links. Pacheco et al..$^{29}$ suggested that HS form micelles having specific sizes, from which it can be inferred that even though $17 \alpha$-ethynylestradiol has a higher molecular mass than bisphenol A, greater Van der Waals type interaction occurs within the HS micelles, due to the larger number of hydrogen atoms present in the molecule. Another important characteristic of HS is
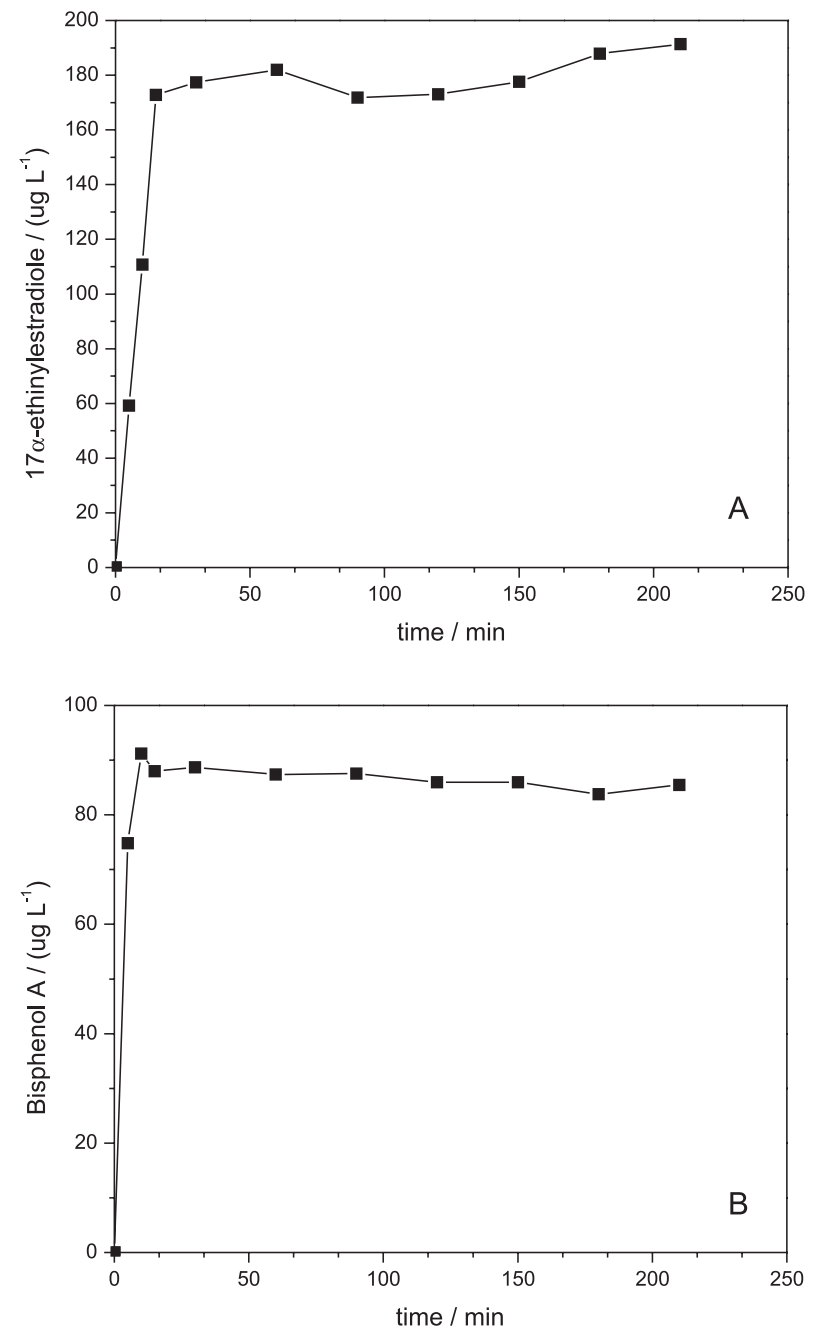

Figure 2. Time for equilibrium between (A) 17 $\alpha$-ethynylestradiol and aquatic humic substances extracted from Ribeira de Iguape River samples, and (B) bisphenol A and aquatic humic substances extracted from Itapanhaú River samples.

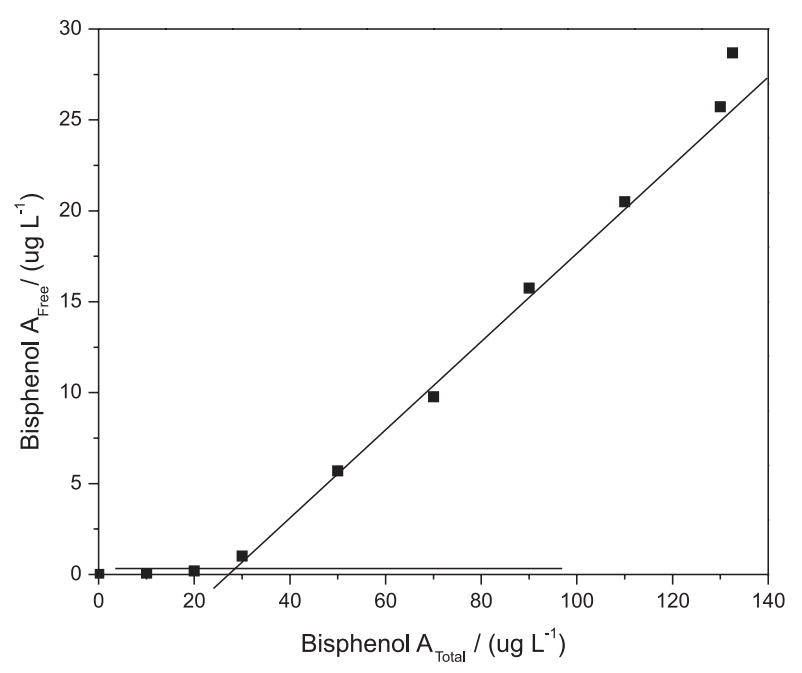

Figure 3. Complexation capacity curve for aquatic humic substances with bisphenol A, using the tangential ultrafiltration technique. Sample concentration: $20 \mathrm{mg} \mathrm{L}^{-1}$; $\mathrm{pH}$ 5.0. 
Table 3. Complexation capacities (CC) of aquatic humic substances for endocrine disruptors and other organic and inorganic substances

\begin{tabular}{lccc}
\hline Species & CC $\left(\mathrm{mg} \mathrm{g}^{-1}\right.$ TOC $)$ & AHS sample & Reference \\
\hline $\mathrm{Cu}$ & 79.40 & Water from the Itapitanguí Stream, São Paulo State & 18 \\
$\mathrm{Cu}$ & 74.90 & Water from the Iguape River, São Paulo State & 18 \\
$\mathrm{Cu}$ & 91.51 & Water from the Rio Negro, Amazon Basin & 18 \\
$\mathrm{Al}$ & $55.90-67.45$ & New Zealand rivers & 28 \\
4-Nitrocathecol & 20.30 & Peat & HA \\
1-Naphthol & 28.40 & Ribeira de Iguape River & This work \\
Bisphenol A & 2.07 & Itapanhaú River & This work \\
Bisphenol A & 1.83 & Ribeira de Iguape River & This work \\
$17 \alpha$-Ethynylestradiol & 18.53 & Itapanhaú River & This work \\
$17 \alpha$-Ethynylestradiol & 16.15 & &
\end{tabular}

LOD ( $\left.\mu \mathrm{g} \mathrm{L} \mathrm{L}^{-1}\right): 8.37$ (bisphenol A); 1.23 (17 $\alpha$-ethynylestradiol). LOQ $\left(\mu \mathrm{g} \mathrm{L}^{-1}\right)$ : 27.45 (bisphenol A); 4.58 (17 $\alpha$-ethynylestradiol).

related to the presence of homologous groups that can form a coating around the AHS complexation sites, which can directly influence the stability of the complexes formed..$^{31}$ Yamamoto et al..$^{32}$ determined the coefficients of sorption of several endocrine disruptors by dissolved organic matter, with the results showing a high affinity of the latter for estrogens (such as $17 \alpha$-ethynylestradiol), and a mechanism involving interaction between d-electrons and hydrogen bonds.

The ED showed a lower affinity for AHS than that exhibited by metal species (Table 3 ), which could be related to the size and steric hindrance of the compounds. However they showed affinities comparable to those of organic compounds such as 4-nitrocathecol and 1-naphthol. ${ }^{29}$ Sun et al. ${ }^{25}$ investigated the coefficients of sorption of three endocrine disruptors by humic substances, and found that sorption was highly dependent on the physico-chemical properties of the humic substances. These findings provide support for the different complexation capacities obtained for the materials used in the present work.

Competition studies are used to evaluate the affinity, for a substrate, of any given compound in relation to others. Figures 5A and 5B illustrate the results obtained for the competition between the ED and the AHS extracted from the Ribeira de Iguape and Itapanhaú rivers, respectively. For both samples there was release of bisphenol A and complexation of 17 $\alpha$-ethynylestradiol, in agreement with the complexation capacity data. The results demonstrate that $17 \alpha$-ethynylestradiol has a greater affinity than bisphenol A for the AHS. Physico-chemical data suggest that the humic molecule possesses a flexible structure as a result of intra/intermolecular interactions and hydrogen bonding. According to Swift, ${ }^{33}$ this flexible structure results in molecules that approximate spheres (micelles), with a Gaussian molar mass distribution and a high mass density in the center, which decreases towards the extremities of the sphere. Furthermore, Hayes et al., ${ }^{34}$ and Ghosh and Shnitzer ${ }^{35}$ state that the dimensions of the sphere depend on factors such as charge density, solvation, ionization of acid groups, branching and cross-linking. Hence, for both of the ED studied, it can be inferred that their main interaction with the AHS was due to hydrogen bonding of the oxygenated groups and $-\mathrm{OH}$ groupings present in the molecules. $17 \alpha$-Ethynylestradiol occupied complexation sites in the humic substance micelles that were previously occupied by bisphenol $\mathrm{A}$, due to the presence of a greater number of hydrogen atoms available for Van der Waals type interactions. The results also show that greater ED complexation occur using AHS extracted from the Ribeira de Iguape River, which is in agreement with the complexation capacity data.

\section{Conclusions}

Studies of complexation between AHS and the endocrine disruptors $17 \alpha$-ethynylestradiol and bisphenol A showed that complexation stability was reached after around $20 \mathrm{~min}$, and that the complexation capacity for $17 \alpha$-ethynylestradiol (16.15-18.53 $\mathrm{mg} \mathrm{g}^{-1}$ TOC) was greater than that for bisphenol A (1.83-2.07 $\mathrm{mg} \mathrm{g}^{-1}$ TOC). The highest complexation capacities were obtained using AHS extracts derived from the Ribeira de Iguape River, which were more aromatic and humified than those from the Itapanhaú River.

Release of bisphenol A and complexation of $17 \alpha$-ethynylestradiol was observed during competition between the ED for AHS complexation sites. This behavior could be related to the greater number of hydrogen atoms 

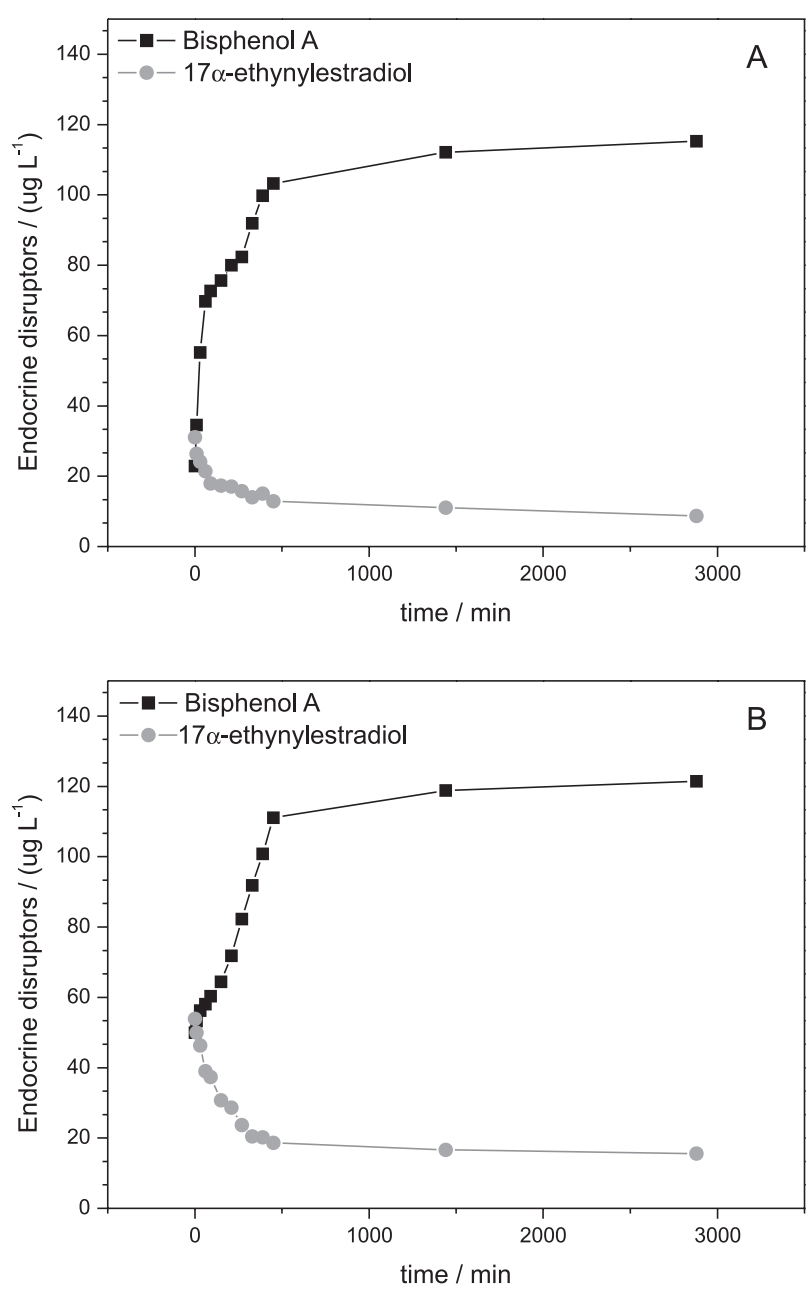

Figure 4. Competition between $17 \alpha$-ethynylestradiol and bisphenol A for AHS extracted from (A) Ribeira de Iguape River samples, and (B) Itapanhaú River samples.

in the $17 \alpha$-ethynylestradiol molecule available for Van der Waals type interactions, enabling the molecule to occupy sites previously complexed by bisphenol A.

These results demonstrate that the availability of endocrine disruptors can be directly influenced by the presence of humic substances in aquatic systems. Consequently, studies of the interactions between AHS and endocrine disruptors are vital for a better understanding of the transport and reactivity of this type of contaminant in the environment.

\section{Acknowledgements}

The authors thank the Fundação de Amparo à Pesquisa do Estado de São Paulo (FAPESP), CAPES and FUNDUNESP for financially supporting this work. The authors are also grateful to Conselho Nacional de Desenvolvimento Científico e Tecnológico (CNPq) for fellowship.

\section{References}

1. Jeannot, R.; Sabik, H.; Sauvard, E.; Dagnac, T.; Dohrendorf, K.; J. Chromatogr., A 2002, 974, 143.

2. Alda, M. J. L.; Barceló, D.; Fresenius J. Anal. Chem. 2001, $371,437$.

3. Ying, G.; Kookana, R. S.; Ru, Y.; Environ. Int. 2002, 28, 545.

4. Rodriguez-Mozaz, S.; Marco, M.; Alda, M. J. L.; Barceló, D.; Anal. Bioanal. Chem. 2004, 378, 588.

5. Sodré, F. F.; Montagner, C. C.; Locatelli, M. A. F.; Jardim, W. F.; J. Braz. Soc. Ecotoxicol. 2007, 2, 187.

6. Billa, D. M.; Dezotti, M.; Quim. Nova 2007, 30, 651.

7. Penteado, J. C. P.; Vaz, J. M.; Quim. Nova 2001, 24, 390.

8. Ghiselli, G.; Jardim, W. F.; Quim. Nova 2007, 30, 695. Reis Filho, R. W.; Araújo J. C.; Vieira, E. M.; Quim. Nova 2006, 29, 817.

9. Lopes, L. G.; Marchi, M. R. R.; Souza, J. B. G.; Moura, J. A.; Lorenzon, C. S.; Cruz, C.; Amaral, L. A.; Quim. Nova 2010, 33,639 .

10. Desbrow, C.; Routledge, E.J.; Brighty, G. C.; Sumpter, J. P.; Waldock, M.; Environ. Sci. Technol. 1998, 32, 1549.

11. Sacher, F.; Lange, F. T.; Brauch, H.; Blankenhorn, I.; German J. Chromatogr. 2001, 938, 199.

12. Johnson, A. C.; Belfroid, A.; Di Corcia, A.; Sci. Total Environ. 2000, 256, 163.

13. Kolpin, D.W.; Furlog, E. T.; Meyer, M. T.; Thurman, E. M.; Zaugg, S. D.; Barber, L. B.; Buxton, H. T.; Environ. Sci. Technol. 2002, 36, 1202.

14. Sun, W. L.; Ni, J. R.; Xu, N.; Sun, L. Y.; Chemosphere 2007, 66, 700 .

15. Rosa, A. H.; Goveia, D.; Bellin, I. C.; Tonello, P. S.; Antunes, M. L. P.; Dias Filho, N. L.; Rodrigues Filho, U. P.; Quim. Nova. 2007, 30, 59.

16. Aiken, G. R.; Wershaw, R. L.; MaCcarthy, P.; Humic Substances in Soil, Sediment and Water-Geochemistry, Isolation and Characterization, $1^{\text {st }}$ ed., Wiley: New York, 1985.

17. Burba, P.; Van den Bergh, J.; Klockow, D.; Fresenius J. Anal. Chem. 2001, 371, 660.

18. Romão, L. P. C.; Castro, G. R.; Rosa, A. H.; Rocha, J. C.; Padilha, P. M.; Silva, H. C.; Anal. Bioanal. Chem. 2003, 375, 1097.

19. Serudo, R. L.; Oliveira, L. C.; Rocha, J. C.; Paterlini, W. C.; Rosa, A. H.; Silva, H. C.; Botero, W. G.; Geoderma 2007, 138, 229.

20. Rosa, A. H.; Simões, M. L.; Oliveira, L. C.; Rocha, J. C.; Martin-Neto, L.; Milori, D. P. M. B.; Geoderma 2005, 127, 1.

21. Rosa, A. H.; Oliveira, L. C.; Bellin, I. C.; Rocha, J. C.; Romão, L. P. C.; Dias-Filho, N. L.; Thermochim. Acta 2005, 433, 77.

22. Stevenson, F. J.; Humus Chemistry, $2^{\text {nd }}$ ed., Wiley: New York, 1994.

23. Oliveira, L. C.; Sargentini Jr., E; Rosa, A. H.; Pereira Jr., O. L.; Simões, M. L.; Martin-Neto, L.; Silva, W. T. L.; Serudo, R. L.; J. Braz. Chem. Soc. 2007, 18, 860. 
24. Rocha, J. C.; Sargentini Jr., E.; Zara, L. F.; Rosa, A. H.; Santos, A.; Burba, P.; Talanta 2003, 61, 699.

25. Sun, W. L.; Ni, J. R.; Liu, T. T.; Water, Air, Soil Pollut. 2006, 6,583 .

26. Santos, A.; Botero, W. G.; Bellin, I. C.; Oliveira, L. C.; Rocha, J. C.; Mendonça, A. G. R.; Godinho, A. F.; J. Braz. Chem. Soc. 2007, 18, 824.

27. Einax, J.; Kunze, C.; Fresenius J. Anal. Chem. 2001, 371, 660.

28. Hawke, D. J.; Powell, K. J.; Gregor, J. E.; Mar. Fresh. Res. 1996, 47, 11.

29. Pacheco, M. L.; Pena-Méndes, E. M.; Havel, J.; Chemosphere 2003, 51, 95 .
30. Chen, S.; Inskeep, W. P.; Williams, S. A.; Callis, P. R.; Soil Sci. Soc. Am. J. 1992, 56, 67.

31. Rocha, J. C.; Rosa, A. H.; Aquatic Humic Substances: Interactions with Metal Species, $1^{\text {st }}$ ed., UNESP: São Paulo, Brasil, 2003.

32. Yamamoto, H.; Liljestrand, H. M.; Shimizu, Y.; Morita, M.; Environ. Sci. Technol. 2003, 37, 2646.

33. Swift, R. S. In Methods of Soil Analysis:Chemical Methods; Sparks, D., ed.; $1^{\text {st }}$ ed., SSSA: Maddison, 1996.

34. Hayes, M. H. B.; Maccarthy, P.; Malcolm, R. L.; Swift, R. S.; Humic Substances II - In Search of Structure, $1^{\text {st }}$ ed., Wiley: New York, 1989.

35. Ghosh, K.; Schnitzer, M.; Soil Sci. 1980, 129, 266.

Submitted: May 28, 2010 Published online: February 17, 2011 